\title{
Development of Creative Thinking as an Essential Competence of a Modern Person
}

\author{
Diana Kolesnikova ${ }^{1},{ }^{*}$ Natalia Bekk ${ }^{1}$, Marika Taybe ${ }^{1}$ \\ ${ }^{1}$ Novosibirsk State University of Architecture, Design and Arts named after A.D. Kryachkov, Novosibirsk, Russia \\ *Email: dikolesnikova@nsuada.ru
}

\begin{abstract}
Modern dynamic life poses extraordinary tasks for each member of society, for which it is necessary to show a creative approach. Creativity is an essential quality for students of the twenty-first century. Currently, there is a substantial scientific, innovative leap in the world; people are increasingly choosing the path of an innovator and inventor. In the age of high technology, for students studying in the direction of Design, it is necessary to think creatively to be in demand in the professional field. The experiment was conducted based on the Novosibirsk State University of Architecture, Design and Arts named after A.D. Kryachkov. We have developed and tested a system of exercises to develop creative abilities within the framework of studying the discipline "design engineering".
\end{abstract}

Keywords: Creativity, Pedagogy, Design, Creative abilities, Art.

\section{INTRODUCTION}

Creativity is required in almost all types of activities. It is understood as a unique system of creative abilities and knowledge, including a different set of components in unique combinations. For example, complex thinking, entrepreneurship and the ability to find non-standard solutions. In current conditions, to meet the mass needs of contemporary society, it is necessary to organise the "in-line" production of creative specialists. There is a need for the purposeful development of creative thinking as one of the essential competencies of a modern person.

The very concepts of creativity and creativity are undergoing significant rethinking today. Several authors (S. Stein, A. Rothenberg, D.R. Housman, A. Hutson) [1], defining the concepts of creativity and creativity, they say that they carry some novelty (i.e., something new is created in the process of creativity). However, at the same time, they emphasise that this "new" should be socially and personally significant, useful. In the works of P.K. Engelmeyer, P.M. Jacobson, L.S. Vygotsky, S.L. Rubinstein, Ya. A. Ponomarev, besides novelty, the essential features of creativity and creativity are exclusivity, difficulty, the suddenness of discovery and randomness of guess [2]. These features distinguish creative activity from reproducing, thereby preventing the purposeful organisation of student creativity in the educational process. Creativity as a creative activity of a person is most closely related to certain qualities in a person and intellectual development [3].

The fundamental tool for developing creative abilities, which has proven its effectiveness, is project activity [4]. Project activity is a special educational, cognitive, creative or game practice of students to achieve a certain goal. In the process, various methods and techniques contribute to the implementation of ideas about the final product in practice. The project as one of the forms of joint activity of the teacher and students allows to develop creativity, promotes the formation of independence, the ability to find and apply knowledge in practice [5].

The project activity contains:

- analysis of the emerging problem;

- $\quad$ setting goals and objectives;

- choosing the means to achieve the project goal;

- searching and processing of information, analysis and synthesis of the received information;

- project implementation;

- the evaluation stage of the obtained results and formulation of conclusions [6].

Scientists agree that project activity is an effective tool for developing a students' personality, including 
developing creativity as the most critical and necessary personality quality today.

The topic under study aims to develop creative abilities in mock-up classes. Based on the formulation of the goal, the following tasks can be identified; in the learning process, it is necessary:

1. To form the ability to generate a large number of ideas in a limited time;

2. To develop the ability to solve non-standard tasks;

3. To form the ability to substantiate a creative idea.

Since the formation of creative abilities will take place based on the subject of design-engineering, two additional tasks should be introduced, such as the development of spatial thinking and 3D modelling and layout skills and the formation of teamwork skills.

\section{RESEARCH METHODOLOGY}

Creative technologies are a system of ways that contribute to the development of creative activity as a conscious, purposeful, manageable and effective process of our activity in all spheres of human life in the context of operational, tactical and strategic goals, with a probable forecast of a creative product [7, p. 146].

All these creative technologies can be combined into three large groups:

1) methods of psychological activation of creative thinking. All the methods of this group are aimed at overcoming psychological barriers that hinder creative thinking. The most widely known method of "brainstorming", proposed by A. Osborne (USA) back in the 1940s. Brainstorming is a method of a collective search for new ideas; the primary meaning is to remove the fear of "saying something wrong" because, firstly, the process of generating ideas and their criticism is separated in time; secondly, it is required to come up with as many ideas as possible in a limited time, thirdly, the atmosphere of universal creativity emotionally "charges" all participants;

2) methods of a systematic search for ideas. The methods of this group allow us to move from a chaotic search for ideas to a structured system. There are many such methods; the most well-known are the following: the method of focal objects, the method of control questions, etc.;

3) methods of controlled search for ideas and development of creative imagination. This group of methods includes methods for developing creative imagination and overcoming the inertia of thinking, developed within the framework of the TSIT - Theory of solving inventive tasks (founder - G.S. Altshuller) [8].

Among the methods of developing creative imagination are the scheme of talented multi-screen thinking, the method of "little men", "goldfish", idealisation of objects. All these techniques represent a precise sequence of mental operations, algorithms, following which ensures overcoming the stereotypical approach, allows you to overcome the inertia of thinking and logically get new ideas.

Thus, the intensive development of creative abilities in the learning process through design-engineering is based on the ability to work in a team, solve complicated problems, the ability to defend and justify your creative idea.

When selecting or developing a methodology for the diagnosis of creativity, it is worth paying attention to ensure that the methodology is reliable, which means that it covers different characteristics of creativity [9].

Scientists consider that the criteria for evaluating a creative solution to a problem are: relevance and social significance; originality; novelty (new content, a combination of traditional, innovative and interactive methods, forms, means of socio-cultural activities); compliance with the achievements of modern science and technology, the successful application of advanced information and media technologies; high efficiency and effectiveness, representativeness; the continuity (the possibility of creative use of other specialists in various socio-cultural organisations and institutions); the prospect (the idea is the future development and application in practice); the elaboration and complexity, expressiveness; the possibility of implementation; economic efficiency and optimal implementation of the idea (assessment idea from the point of view of the correlation of performance and financial, time, personnel costs for these results $[10,11])$.

Considering these positions, the following criteria were derived: ease of generating ideas; ease of association; interest in solving non-standard tasks; anticonformism of thinking; justification of a creative project; originality of the justification of a creative project.

\subsection{Conducting an experiment}

In the experiment, the following hypothesis was tested: if you use exercises to develop creativity in design classes, you will be able to develop semantic flexibility of thinking in students, the ability to generate many ideas, and the ability to justify a creative idea.

To achieve this goal, the tasks of the formative stage of the experiment were determined:

- to develop an experimental program for developing creative abilities in teaching design-engineering to students.

- to test the experimental program, to study its effectiveness to develop creative abilities in practice. 
For the accuracy of the experiment, it was decided to divide the groups into experimental and control groups.

The experimental program consists of 3 parts. The first stage of the experimental program was "Acquisition of primary skills of creative abilities". At this stage, the following tasks were solved: developing threedimensional thinking and the skill of layout and 3D modelling, developing the ability to generate many ideas in a limited time and learning how to solve non-standard tasks. Pedagogical conditions for implementing this stage were: providing a favourable and creative atmosphere in the classroom, rejecting criticism and value judgments, providing an esthetical environment, and developing the creative activity.

In the experimental group, during the first classes, the rule was adopted that when criticising another student's idea, the critic should justify his opinion and offer his solution to this problem. The rules are observed by all members of the group and the teacher.

For the correctness of comments on the quality of the student's work, the teacher, before commenting, finds three points in the student's work that he likes; only then adjustments are made to the project by the teacher. This method helps raise the confidence of a teenager and not get upset when making a mistake. The student is selfconfident, more creative, does not hesitate to express his thoughts and ideas in creating a design product.

At the first stage, the student learns to express his thoughts on paper. The sketching technique is used to convey ideas.

At the sketching stage, the exercise "Strange Customer" developed by us was introduced.

This exercise is based on the method of solving case problems. The exercise involves dividing the group into teams ( 3 to 5 people). After the division, each of the participants writes three cards. On the first card, there was an object (a table, a car, a vacuum cleaner, etc.), on the second material (glass, plastic, metal, etc.), on the third, a brief portrait of the consumer (Vasya is an 11thgrade student, likes to wear sneakers; Zinaida Ivanovna works as a music teacher, does yoga).

The next step is to fold all the cards and put them in three boxes. After each team pulls one card from each box. Before starting the design, each team has a card on the table with an object that they will develop, with the material of which material this object is made and a third card on which the consumer is indicated who will use this object.

After studying the information, the guys begin to design one item as a team. During the design process, timing consists of generating ideas, performing the technical part, preparing for protection, protecting the project.
After the project is developed, students defend their projects in front of an audience consisting of other groups. In defence, it is important to tell and prove to the audience that this particular material should be used in this project for this person. In the more complex configuration of this exercise, the audience asks questions that hinder the successful defence of the project, and the speakers must quickly come up with a creative answer to the audience's question.

The exercise is aimed at solving non-standard problems, the ability to generate ideas in a limited time, and the ability to work in a team. Also, thanks to the "playful form of papers", the guys working on the project were more relaxed, and the atmosphere in the audience became friendly. These indicators influence creating a favourable creative and pedagogical environment, namely, the interaction between students.

At the second stage, when the design of the object is invented, the shape of the product is tested, its ergonomics are tested by the layout method.

An exercise was developed and tested to transform a simple shape, namely a cube, into a more complex one. Students could divide the cube compositionally, but the shape itself could not be broken. The method of solving open-inventive tasks, as well as the reproductively creative method, was used. Most students perceived the cube as a box and created new options for opening the package based on the existing form.

The third stage of design is 3D modelling.

The purpose of the 3D modelling exercises was to develop the level of spatial thinking, creative and creative abilities, and the ability to solve open problems, which is one of the main components of a creative person.

During the lesson, an experiment was conducted to consolidate the acquired skills; one group was asked to choose a design subject independently, the other group needed to design their cell phone in the program. An open task was set, tools were given, but no specific sequence algorithm was used. For the first group, the task was more complicated since each student had to come up with a way to make this or that detail himself, and for the second group, since the subjects were similar and had minor differences, the task was easier. During the experiment, it was revealed that students designing different subjects mastered the solid-state modelling module faster.

Students from the first group chose the subject of design themselves. It was more challenging to work with this group since everyone had to devote sufficient time. At the same time, the guys, realising that perhaps their turn of consultation would not come soon, began to listen to the methods of manufacturing this or that part of the subject; when the consultation for other students took place, they tried to apply this method of design to their product details. Also, the guys from this group planned 
the method of designing parts in advance and receiving tips actively used them. It was easier for this group to cope with the load in subsequent classes.

\section{RESEARCH RESULTS}

To determine the level of creative thinking, the divergent thinking test by F. Williams was chosen and the criteria and indicators developed by us for evaluating students' creative work. At the beginning of the training, the test results of the two groups were in the same range.

The criteria used to evaluate students' work are listed below:

Accuracy - this criterion assesses the quality of the project made, in layout, it is the cleanliness of paperwork, the absence of glue and pencil marks on the layout, in 3D modelling, this indicator indicates the cleanliness of the assembly, namely the rupture of parts, the intersection of planes, the reduction of points into one.

Composition - the key component of a successful design project or layout is composition. The human eye is used to divide an object by a grid. Therefore, for the product to successfully enter the market, it is necessary to pay attention to the composite grid initially. The composite grid is considered in graphic design and is also vital in subject design. When creating a product design layout, it is recommended to build the composition correctly.

Scale - the sense of scale affects the design of the product; when building a layout or model, a competent construction is necessary since, at the layout stage, it is possible to understand the ergonomics of the product about a person. An incorrectly executed layout will mislead the designer; as a result, the products will go into production with the wrong dimensions. Students, as future specialists, need to learn how to build layouts and models at scale.

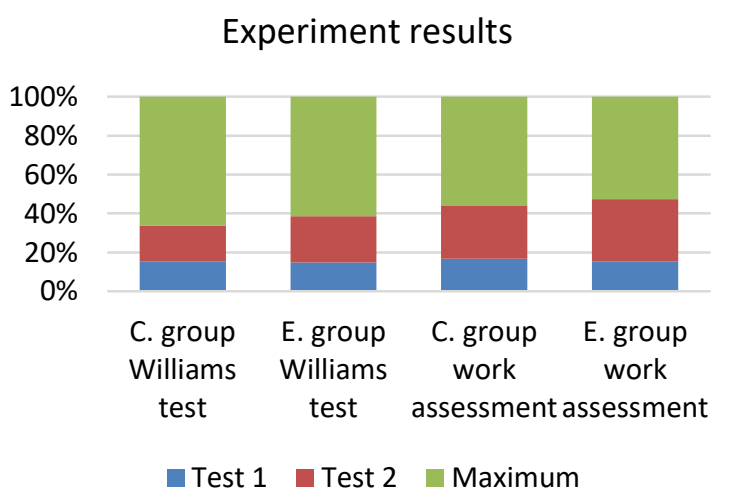

Figure 1 Experiment results.

Completeness - creating a design object involves bringing the object to the final form; not all students manage to finish the layout. Therefore, it is necessary to introduce the completeness criterion into the evaluation system.

At the end of the experiment, repeated testing and assessment of the level of work was carried out; the results are shown in Figure 1. The control group consisting of 11 students improved their performance by $5 \%$, the experimental group consisting of 10 people by $15 \%$ according to the Williams test, according to the criteria developed by us, the indicators of the first group improved by $19 \%$, the second by $32 \%$.

\section{CONCLUSION}

Pedagogical conditions for the development of creative abilities were involved at every stage. In the process of implementing pedagogical conditions at the stage of the formative experiment, the interior of the room where the training took place was changed, rules on the absence of unreasonable criticism between the participants of the experiment were introduced, the comments rule "three to one" was introduced when expressing comments three times praise, then criticise, activation of creative activity was carried out using methods of observation and problem solving, exercises were introduced to develop teamwork skills, during the last year of study, students actively participated in Russian and international competitions.

At the stage of the formative experiment, such methods as a reproductive-creative approach, teamcompetitive work, the method of case-learning and solving open problems, heuristic teaching methods were used, when a student lagged behind the main educational program, the method of individual training was used, as well as an exercise system based on the Fusion 360 CAD was developed.

At the end of the experiment, tests were repeated, which showed the dynamics of the development of creative abilities in the experimental group to a greater extent than in the control groups.

Comparing the two groups, the control and the experimental, it is safe to say that the experimental group exceeded the indicators of the control group in terms of overall averages. The developed technique gave positive results and achieved its goal.

\section{REFERENCES}

[1] Yu.G. Volkov, Creativity: Russia's Historical Breakthrough [Kreativnost': istoricheskij proryv Rossii]. Moscow, 2011.

[2] L.V. Romanyuk, Humanistic Pedagogy [Gumanisticheskaya pedagogika], Knowledge. Understanding. Skill [Znanie. Ponimanie. Umenie] 2 (2012) 304-307 p. 
[3] K.G. Krechetnikov, Designing a creative educational environment based on information technologies at a university [Proektirovanie kreativnoj obrazovatel'noj sredy na osnove informacionnyh tekhnologij $\mathrm{v}$ vuze], Moscow: Goskortsentr, 2002, 296 p.

[4] D.B. Bogoyavlenskaya, Psychology of creative abilities: monograph [Psihologiya tvorcheskih spoonist: monografiya], Samara: Educational literature [Uchebnaya literatura], 2009, 416 p.

[5] Soraia Garcés, CREATIVITY IN SCIENCE DOMAINS: A REFLECTION, Atenea (Concepc.) No. 517, 2018. DOI: https://doi.org/S0718$\underline{04622018000100241}$

[6] A. Schmidt, Creativity in Science: Tensions between Perception and Practice, Creative Education, No. 2001. DOI: https://doi.org/10.4236/ce.2011.25063

[7] I.B. Novik, On modelling complex systems (philosophical essay) [O modelirovanii slozhnyh sistem (filosofskij ocherk)], Moscow, 1965, 42 p.

[8] A.A. Gin, What is TSIT-pedagogy "Education for a new era" [Chto takoe TRIZ-pedagogika «Obrazovanie dlya novoj ery»]. 2018. Retrieved from: https://trizway.com/info/triz-pedagogy.html

[9] K.S. Aibatyrov, Modern scientific and pedagogical ideas about creativity [Sovremennye nauchnopedagogicheskie predstavleniya o kreativnosti], Bulletin of the Maikop State Technological University [Vestnik Majkopskogo gosudarstvennogo tekhnologicheskogo universiteta], No. 2, 2014.

[10] A. Richardson, The Science of Creativity, 2018, 96 p.

[11] J. Gilford, "Intelligence, creativity and their educational significance", R.R. Knapp, 1968, p. 229. 